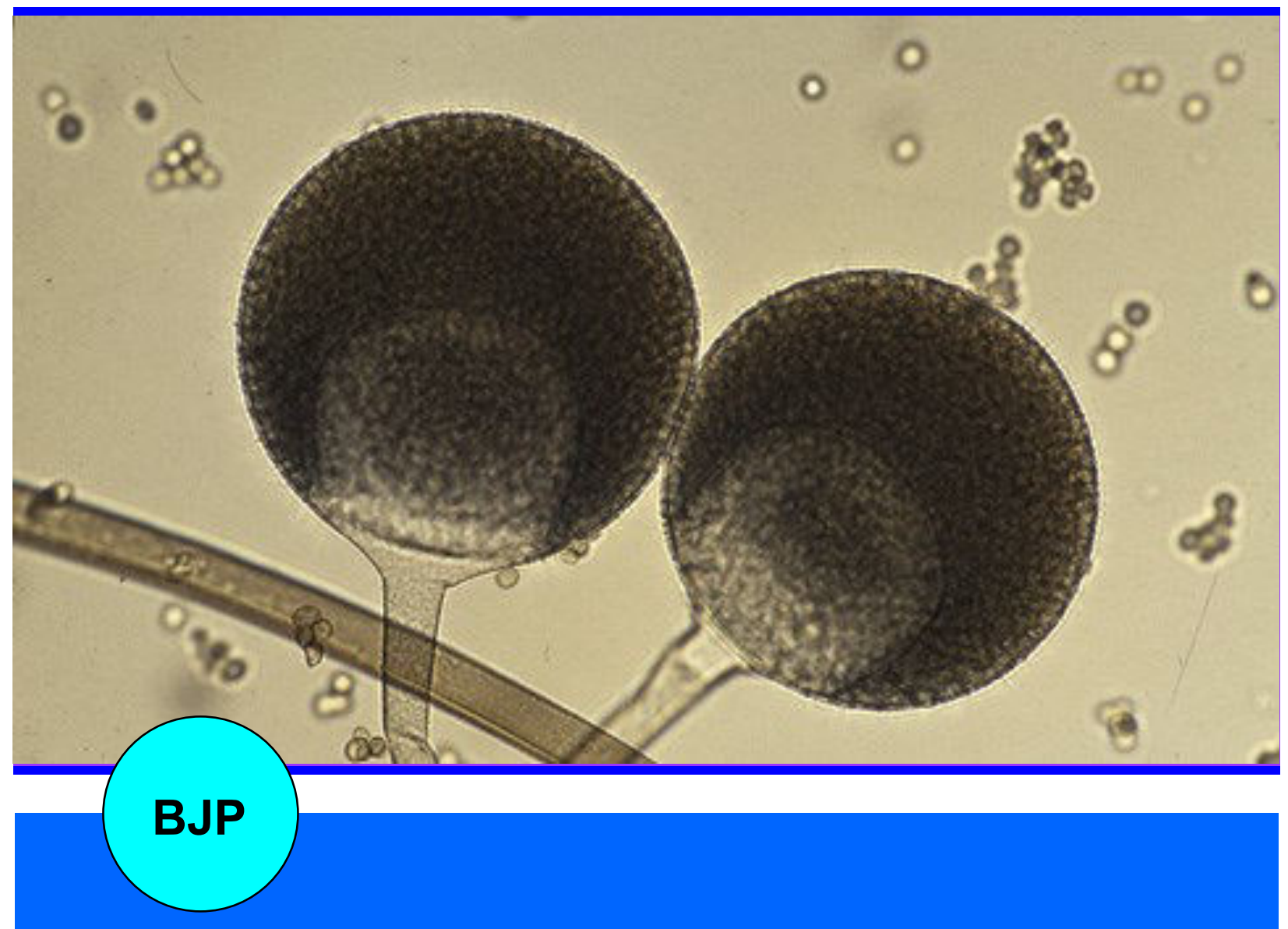

Bangladesh Journal of Pharmacology

Research Article

Antihepatotoxic effect of isolated chitin from Rhizopus oryzae against paracetamol-induced hepatotoxicity 


\title{
Antihepatotoxic effect of isolated chitin from Rhizopus oryzae against paracetamol-induced hepatotoxicity
}

\author{
Akila Ramanathan and Ramya Kittusamy \\ Department of Pharmaceutical Biotechnology, College of Pharmacy, Sri Ramakrishna Institute of Paramedical \\ Sciences, Coimbatore 641 044, Tamil Nadu, India.
}

\begin{tabular}{|c|c|}
\hline \multicolumn{2}{|l|}{ Article Info } \\
\hline $\begin{array}{l}\text { Received: } \\
\text { Accepted: } \\
\text { Available Online: }\end{array}$ & $\begin{array}{r}5 \text { September } 2011 \\
18 \text { September } 2011 \\
27 \text { September } 2011\end{array}$ \\
\hline DOI: $10.3329 /$ bjp.v & $6 \mathrm{i} 1.8556$ \\
\hline $\begin{array}{l}\text { Cite this article: } \\
\text { Ramanathan A, K } \\
\text { hepatotoxic effect } \\
\text { from Rhizopus oryz } \\
\text { mol-induced hepa } \\
\text { desh J Pharmacol. }\end{array}$ & $\begin{array}{l}\text { ittusamy R. Anti- } \\
\text { of isolated chitin } \\
\text { ae against paraceta- } \\
\text { totoxicity. Bangla- } \\
\text { 2011; 6: 64-67. }\end{array}$ \\
\hline
\end{tabular}

\begin{abstract}
The present study was aimed at investigating the antihepatotoxic activity of isolated fungal chitin, a natural polysaccharide from Rhizopus oryzae NCIM1009 against paracetamol-induced toxicity in rats. Changes in the levels of biochemical markers of hepatic injury such as serum glutamate oxaloacetic transaminase (SGOT), serum glutamic pyuruvic transaminase (SGPT), alkaline phosphatase, bilirubin and total protein were determined in both treated and control group of rats. The effect of fungal chitin was compared with that of silymarin $(25 \mathrm{mg} / \mathrm{kg})$. The results showed that paracetamol $(750$ $\mathrm{mg} / \mathrm{kg}$ ) elevated the levels of biomarkers enzymes. Treatment with fungal chitin $(200 \mathrm{mg} / \mathrm{kg})$ brought the marker level near to normal and showed significant hepatoprotective activity. Acute toxicity studies of fungal chitin was carried out and found safe up to $2,000 \mathrm{mg} / \mathrm{kg}$. The isolated fungal chitin was characterized by IR spectroscopy and compared with commercial chitin.
\end{abstract}

\section{Introduction}

Liver is the most important organ, which plays a pivot role in regulation of physiological process (Sahani, 1999). It is involved in several vital functions such as metabolism, secretion and storage. It has great capacity to detoxicate the toxic substances. Liver disease is a world wide problem and are mainly caused by toxic chemicals (certain antibiotics, chemotherapeutics, peroxidised oil, chlorinated hydrocarbons, etc.) excess consumption of alcohol, infections and autoimmune disorder (Recknagel 1983; Wendel et al., 1987; Muriel and Rivera-Espinoza, 2008). Most of the hepatotoxic chemicals damage liver cells by inducing lipid peroxidation and other oxidative damages in liver. In absence of reliable liver protective drugs in modern medicine, there exists a challenge for pharmaceutical scientists to explore the potential of hepatoprotective activity using natural sources.
Chitin is a polysaccharide composed of N-acetyl-Dglucosamine units. It is the second most abundant natural polysaccharide and found mainly in invertebrates, insects, marine diatoms, algae, fungi and yeasts. Chitin has unique properties, which make them useful for variety of applications in pharmaceutical, medicine, food, agriculture, textile and paper industries (Kurita, 1998; Felse and Panda, 1999; Kumar, 2000; Tharanathan and Kittur, 2003). The traditional source of chitin is shellfish waste from shrimp, antartic krill, crab and lobster processing. However, the industrial isolation of this polysaccharide is reduced by the problems of seasonal and limited supply in some countries and environmental pollution while collecting large amounts of shell waste (White et al., 1979).

Owing to unique biological properties of chitin, much attention has been given to the study of its applications. However, most of its biological properties remain to be 
studied. To overcome the above disadvantages in traditional production of chitin and in the study of its biological properties, As an alternative, an attempt has been made in the present work, to obtain fungal chitin isolated from Rhizopus oryzae NCIM 1009 and its hepatoprotective activity was studied.

\section{Materials and Methods}

\section{Culture and its maintenance}

The microorganism used in this study was Rhizopus oryzae NCIM1009 obtained from National chemical laboratory, Pune, India.The fungus was maintained at $4^{\circ} \mathrm{C}$ on PDF slant and transferred on a monthly basis.

\section{Cultivation conditions}

The standard inoculum was prepared by the spores of Rhizopus oryzae NCIM1009, harvested from 7 days petriplate culture on PDA medium at $28^{\circ} \mathrm{C}$. The spore suspension was prepared and adjusted to $10^{8}$ spores/ $\mathrm{mL}$ using a hematocytometer for counting (Thayza et al., 2007).

The fermentation broth consisted (g/L) of glucose (20), peptone (10), yeast extract (1), ammonium sulfate (5), dipotassium hydrogen orthophosphate (1), sodium chloride (1), magnesium sulphate 7-hydrate (5), and calcium chloride 2-hydrate (0.1). The $\mathrm{pH}$ of the YPD broth was adjusted to 4.5 using dilute $\mathrm{HCl}$ and autoclaved at $121^{\circ} \mathrm{C}$ for $15 \mathrm{~min}$ (Chen et al., 1999).

For submerged cultivation $10 \% \mathrm{v} / \mathrm{v}$ of the standard inocula was inoculated to $300 \mathrm{~mL}$ of fermentation broth in the seven $500 \mathrm{~mL}$ capacity Erlenmeyer flasks and incubated at $28^{\circ} \mathrm{C}$ for 7 days in a rotary shaker at 200 rpm. The experiment was carried out in triplicate and the results are expressed as mean $\pm \mathrm{SD}$.

\section{Chitin isolation}

After cultivation of culture in fermentation broth, the fungal mycelia was harvested for every 24 hours by filtration (No.1; Whatman) washed with distilled water until a clear filtrate was obtained and then dried at $60^{\circ} \mathrm{C}$ to a constant weight. The chitin isolation was carried out by suspending the fungal mycelia with $1 \mathrm{M} \mathrm{NaOH}$ solution $(1: 30 \mathrm{w} / \mathrm{v})$ and autoclaved at $121^{\circ} \mathrm{C}$ for $15 \mathrm{~min}$. The alkali insoluble fractions were collected after centrifugation at $12,000 \mathrm{x} \mathrm{g}$ for $15 \mathrm{~min}$. The residues were further extracted using $10 \%$ acetic acid (1:40\% w/ v) at $60^{\circ} \mathrm{C}$ for 6 hours. The resulting slurry was isolated by filtration containing acid insoluble material chitin. The isolated fungal chitin was then washed with distilled water, $95 \%$ ethanol $(1: 20 \mathrm{w} / \mathrm{v})$, acetone $(1: 20$ $\mathrm{w} / \mathrm{v}$ ) and dried at $60^{\circ} \mathrm{C}$ to a constant weight (Pochanavanich and Suntornsuk, 2002).

\section{Chitin characterization}

The IR spectra of the $\mathrm{KBr}$ discs containing chitin and compared with commercial chitin (Cochin Fisheries, Cochin) were measured from $4000 \mathrm{~cm}^{-1}$ to $400 \mathrm{~cm}^{-1}$ with a JASCO FT-IR spectrophotometer.

\section{Chemicals}

All chemicals were of high quality from HI-Media Laboratories, Mumbai.

\section{Experimental animals}

Male Swiss albino mice weighing between 20-25 g and male Wistar albino rats weighing between 150-220 g were used. The animals were placed at random and allocated to treatment groups in polypropylene cages with paddy husk as bedding. Animals were housed at a temperature of $24 \pm 2^{\circ} \mathrm{C}$ and relative humidity of 30 $70 \%$. A 12:12 hours light:dark cycle was followed. All animals were allowed to free access to water and fed with standard commercial pelleted rat chaw (M/s. Hindustan Lever Ltd, Mumbai). All the experimental procedures and protocols used in this study were reviewed by the Institutional Animal Ethics Committee and were in accordance with the guidelines of the Committee for the Purpose of Control and Supervision on Experiments on Animals (CPCSEA).

\section{Acute toxicity study}

A safe oral dose of the extract was determined by acute oral toxic class method of Economic Co-operation and Development (OECD) as per 425 guidelines (OECD 2000). Swiss albino mice were kept overnight fasting and food was with held for 3-4 hours prior to isolated chitosan administration. A total of five animals were used which received a single oral dose $(2,000 \mathrm{mg} / \mathrm{kg}$ b.w.) of isolated chitosan. Animals were observed individually at least once during the first $30 \mathrm{~min}$ after dosing, periodically during the first 24 hours (with special attention during the first 24 hours) and daily thereafter for a period of 14 days. No mortality was found even at 2,000 mg/ kg. The dose of $200 \mathrm{mg} / \mathrm{kg}$, p.o. was selected for the further activity.

\section{Anti-hepatotoxic activity in paracetomol induced liver toxicity rat model}

The experiment was carried out after obtaining clearance from Institutional Animal Ethics Committee. The animals were divided in to 5 groups of 6 animals each. Animals were divided into five groups of 6 animals each. Group I served as control, which received normal saline $5 \mathrm{~mL} / \mathrm{kg}$ orally for 7 days. Group II received paracaetmol $750 \mathrm{mg} / \mathrm{kg}$, Group III and IV received isolated chitin $(200 \mathrm{mg} / \mathrm{kg}, 400 \mathrm{mg} / \mathrm{kg}$ respectively) for 7 days and Group V received standard drug silymarin $25 \mathrm{mg} / \mathrm{kg}$.

On the $7^{\text {th }}$ day, after 1 hour of administration of various doses of isolated chitin $(200 \mathrm{mg} / \mathrm{kg}$ and $400 \mathrm{mg} / \mathrm{kg}$ ) to 
group III and IV and silymarin to Group V, paracetamol suspension was given orally to all groups of rats except the rats in Group I. On the $8^{\text {th }}$ day, the blood sample was collected by cardiac puncture after euthanasia with diethyl ether and centrifuged at $200 \mathrm{rpm}$ for $15 \mathrm{~min}$ to separate the serum for various biochemical estimations. The serum activities of serum hepatic marker enzymes namely SGOT, SGPT, ALP (Reitman and Frankel, 1957), bilirubin (Kind and King, 1954; Jendrassik and Grof, 1938) and total protein were assayed.

\section{Statistical analysis}

The values were expressed as mean \pm SEM. The statistical analysis was carried out by one way analysis of variance (ANOVA) followed by Dunnet's t-test. P values $<0.01$ were considered significant.

\section{Results and Discussion}

The chitin was isolated from fungus Rhizopus oryzae NCIM 1009, characterized by IR (Figure 1 and 2) and screened for antihepatotoxic activity. Acute toxicity study was first determined and found safe up to 2,000 $\mathrm{mg} / \mathrm{kg}$ body weight. Hence, the antiulcer activity was studied at 200 and at $400 \mathrm{mg} / \mathrm{kg}$. The levels of hepatic marker enzymes SGOPT, SGPT, ALP, bilirubin and total protein was elevated in paracetamol treated animals when compared to control groups (Table I). The isolated fungal chitin and silymarin treatment decreases the levels of SGOT, SGPT, ALP and total protein when compared to paracetamol treated groups.

Injury to hepatocyte and bile duct cells leads to accumulation of bile acid inside liver. This promotes further liver damage. Biochemical parameters are often used to indicate liver damage. Elevated levels of serum enzymes are indication of cellular leakage and loss of functional integrity.

As chitin is made up of N-acetyl-D-glucosamine units its anti hepatotoxic activity may be due to the presence of glucosamine units as they play an important role in detoxification of liver by strengthening the antioxidant defensive system in the body to counteract any

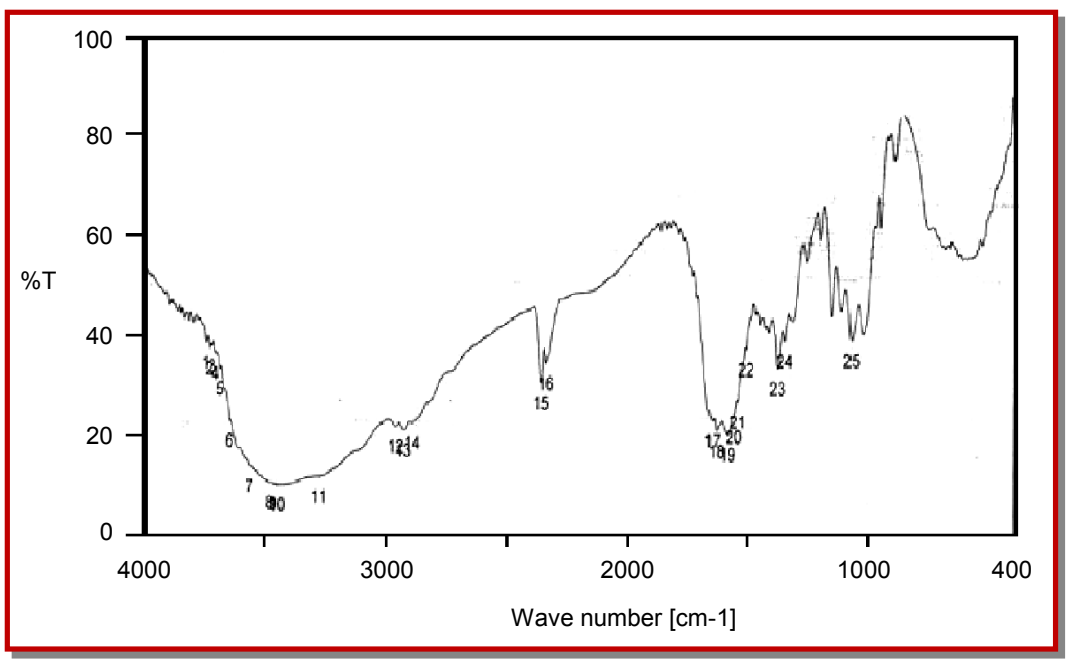

Figure 1: IR Spectra of commercial chitin from Cochin fisheries, Cochin

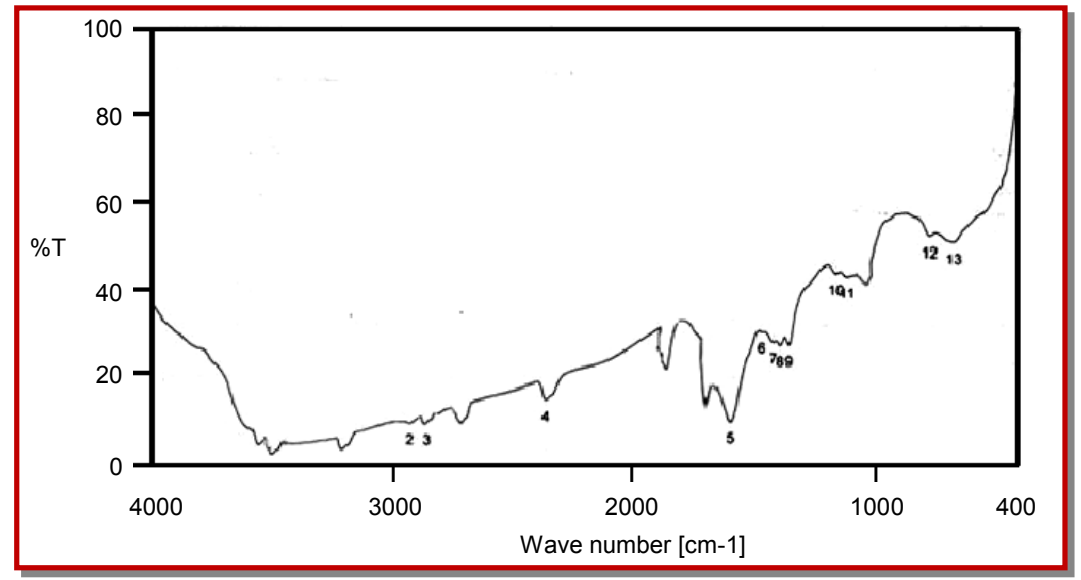

Figure 2: IR Spectra of isolated chitin from Rhizopus oryzae NCIM1009 
Table I

Biochemical parameters of hepatoprotective activity of chitin

\begin{tabular}{|c|c|c|c|c|c|c|}
\hline Group & Treatment & $\begin{array}{l}\text { SGOT } \\
\text { IU/L }\end{array}$ & $\begin{array}{l}\text { SGPT } \\
\text { IU/L }\end{array}$ & $\begin{array}{l}\text { ALP } \\
\text { IU/L }\end{array}$ & $\begin{array}{c}\text { Bilirubin } \\
\mathrm{mg} / \mathrm{dL}\end{array}$ & $\begin{array}{c}\text { Total protein } \\
\mathrm{g} / \mathrm{dL}\end{array}$ \\
\hline I & Normal saline ( $5 \mathrm{~mL} / \mathrm{kg}$ orally) & $0.4 \pm 0.1$ & $0.5 \pm 0.8$ & $2.3 \pm 0.2$ & $1.9 \pm 0.2$ & $1.5 \pm 0.4$ \\
\hline II & Paracetamol (750 mg/kg orally) & $1.9 \pm 0.2^{\mathrm{a}}$ & $1.7 \pm 0.1^{\mathrm{a}}$ & $4.2 \pm 0.7^{a}$ & $3.1 \pm 0.1^{\mathrm{a}}$ & $3.0 \pm 0.1^{\mathrm{a}}$ \\
\hline III & Paracetamol + Fungal chitin ( $200 \mathrm{mg} / \mathrm{kg}$ orally $)$ & $0.3 \pm 0.1^{a}$ & $0.3 \pm 0.0^{*}$ & $2.1 \pm 0.1^{\mathrm{a}}$ & $1.6 \pm 0.6^{a}$ & $1.0 \pm 0.9^{a}$ \\
\hline IV & Paracetamol + Fungalchitin $(400 \mathrm{mg} / \mathrm{kg}$ orally $)$ & $0.3 \pm 0.0^{\mathrm{a}}$ & $0.4 \pm 0.2^{\mathrm{a}}$ & $2.2 \pm 0.2^{\mathrm{a}}$ & $1.9 \pm 0.0^{a}$ & $1.0 \pm 0.1^{\mathrm{a}}$ \\
\hline V & Paracetamol + Silymarin $(25 \mathrm{mg} / \mathrm{kg}$ orally $)$ & $0.3 \pm 0.1^{a}$ & $0.4 \pm 0.0^{a}$ & $2.2 \pm 0.8^{a}$ & $1.7 \pm 0.2^{b}$ & $1.0 \pm 0.1^{a}$ \\
\hline
\end{tabular}

Values are mean $\pm \mathrm{SEM} ; \mathrm{n}=6$; $\mathrm{a}<<0.01$ when compared to control; ap $<0.01$ and ${ }^{\mathrm{b}} \mathrm{p}<0.05$ when compared to paracetamol control (One-way ANOVA followed by Dunnett's Test)

oxidative damage caused to the liver (Zupanets et al., 1990; Yan et al., 2006). The results of this study clearly demonstrated that the isolated fungal chitin at a dose of $200 \mathrm{mg} / \mathrm{kg}$ body weight, prevents liver damage against paracetamol induced toxicity.

\section{Acknowledgement}

The authors are thankful to Dr. S. Krishnan, Department of Biotechnology, College of Pharmacy, Sri Ramakrishna Institute of Paramedical Sciences, Coimbatore for providing necessary facilities to carry out this work.

\section{References}

Chen MH, Chan HY, Wu CL. Food industry research and development institute. Production of chitosan and chitin. US patent 6255085, 1999.

Felse AP, Panda T. Studies on application of chitin and its derivatives. Bioprocess Eng. 1999; 20: 505-15.

Jendrassik L, Grof P. Simplified photometric methods for the determination of the blood bilirubin. Biochemische Zeitschrift. 1938; 297: 81-89.

Kind PRN, King EJ. Estimation of plasma phosphatase by determination of hydrolysed phenol with aminoantipyrine. J Clin Pathol. 1954; 7: 322-26.

Kumar NVRM. A review on chitin and chitosan applications. React Funct Polymer. 2000; 46: 1-27.

Kurita K. Chemistry and application of chitin and chitosan. Polym Degrad Stabil. 1998; 59: 117-20.

Muriel P, Rivera-Espinoza Y. Beneficial drugs for liver disease.
J Appl Toxicol. 2008; 28: 93-103.

OECD. Acute and toxicity-acute and toxic class method guideline 423. In: Eleventh addendum to the OECD guidelines for the testing of chemicals. Paris, Organization for economic co -operation and development, 2000.

Pochanavanich P, Suntornsuk W. Fungal chitosan production and its characterization. Lett Appl Microbiol. 2002; 35: 17-21.

Recknagel RO. A new direction in the study of carbon tetrachloride hepatotoxicity. Life Sci. 1983; 33: 401-08.

Reitman S, Frankel S. A colorimetric method for the determination of serum glutamic oxalacetic and glutamic pyruvic transaminases. Am J Clin Pathol. 1957; 28: 56-63.

Sahani S. Evaluation of hepatoprotective efficacy of APCL- A poly herbal formulation in vivo in rats. Indian drugs. 1999; 36: 628-31.

Thayza CMS, Tania LMS, Newton PS, Benicio BN, Galba Maria CT. Growth of Cunninghhamella elegans UCP 542 and production of chitin and chitosan using yam bean medium. Electron J Biotechnol. Chile 2007; 10: N1.

Wendel A, Feuersteins S, Konz KH. Acute paracetamol intoxication of starved mice leads to lipid peroxidation in in vivo. Biochem Pharmacol. 1987; 28: 2051-53.

White SA, Farina PR, Fulton I. Production and isolation of chitosan from Mucor rouxii. Appl Environ Microbiol. 1979; 38: 323-28.

Yan Y, Wanshun L, Baoqin H, Bing L, Chenwei F. Protective effects of chitosan oligosaccharide and its derivative against carbon tetrachloride-induced liver damage in mice. Hepatol Res. 2006; 35: 178-84.

Zupanets IA, Drogovoz SM, Lakovleva LV, Pavlii AI, Bykova OV. Physiological importance of glucosamine. Fiziol $\mathrm{Zh}$. 1990; 36: 115-20. 